\title{
Enrichment of Protein-RNA Crosslinks from Crude UV-lradiated Mixtures for MS Analysis by On-Line Chromatogyraphy Using Titanium Dioxide Columns
}

\author{
Florian Martin Richter, He-Hsuan Hsiao, Uwe Plessmann, Henning Urlaub \\ Bioanalytical Mass Spectrometry Group, Max-Planck-Institute for Biophysical Chemistry, Am Fassberg 11, \\ D-37077 Göttingen, Germany
}

Received 12 September 2008; revised 19 December 2008; accepted 24 December 2008

Published online 12 January 2009 in Wiley InterScience (www.interscience.wiley.com). DOI 10.1002/bip.21139

\section{ABSTRACT:}

UV crosslinking is an appropriate method to identify proteins that directly contact nucleic acid, e.g., RNA. In combination with modern mass spectrometric (MS) analysis such an approach provides the opportunity to reveal not only the nature of the crosslinked proteins but also to identify the actual crosslinking sites between the protein and the nucleic acid. However, the relatively low yield in UV-induced crosslinking makes it difficult to identify in particular those species by MS that represent peptide-nucleic acid conjugates, as the great excess of noncrosslinked material interferes with their detection in MS. Here, we present an automated enrichment strategy of crosslinked peptide-RNA oligonucleotides derived from crude mixtures of $U V$-irradiated ribonucleoprotein (RNP) particles that uses $\mathrm{TiO}_{2}$ columns integrated within a two-dimensional (2D) nanoliquid chromatography (LC) system. The setup combines two C18 precolumns, a $\mathrm{TiO}_{2}$ enrichment column and a nanoanalytical column. It allows the removal of the noncrosslinked RNA and protein moiety and the specific enrichment of crosslinked peptide-RNA conjugates so that UV-irradiated and subsequently completely hydrolyzed RNP complexes can directly be loaded and analyzed by MS. In this feasibility study, we demonstrate the specific enrichment of peptide-

Correspondence to: Henning Urlaub; e-mail: henning.urlaub@mpibpc.mpg.de Contract grant sponsor: YIP (EURASNET)

(C) 2009 Wiley Periodicals, Inc.
$R N A$ oligonucleotides derived from $U V$-irradiated native spliceosomal U1 snRNPs and spliceosomal [15.5K-61KU4atac snRNA] complex reconstituted in vitro. (C) 2009 Wiley Periodicals, Inc. Biopolymers 91: 297-309, 2009. Keywords: 2D liquid chromatography; crosslinking; protein; RNA; titanium dioxide

This article was originally published online as an accepted preprint. The "Published Online" date corresponds to the preprint version. You can request a copy of the preprint by emailing the Biopolymers editorial office at biopolymers@wiley. com

\section{INTRODUCTION}

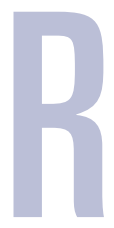

ibonucleoprotein (RNP) particles play essential roles in a number of fundamental cellular processes, including pre-mRNA splicing. ${ }^{1-4}$ Detailed knowledge of contact sites between proteins and RNA within the RNP is crucial for a profound understanding of their functions. In the absence of high-resolution structures of protein-RNA complexes, UV crosslinking at $254 \mathrm{~nm}$ combined with mass spectrometry (MS) is a powerful and straightforward tool to identify such contact sites in purified native RNPs. ${ }^{5,6}$ However, a bottleneck of this approach has always been the low yield of protein-RNA crosslinking, when nonmodified RNA - as present in native particles-is used. Therefore, the purification of the crosslinked species over the excess of noncrosslinked peptide and RNA moieties is the essential step in the analysis.

In recent years we have used size-exclusion (SE) chromatography of UV-irradiated and subsequently hydrolyzed 

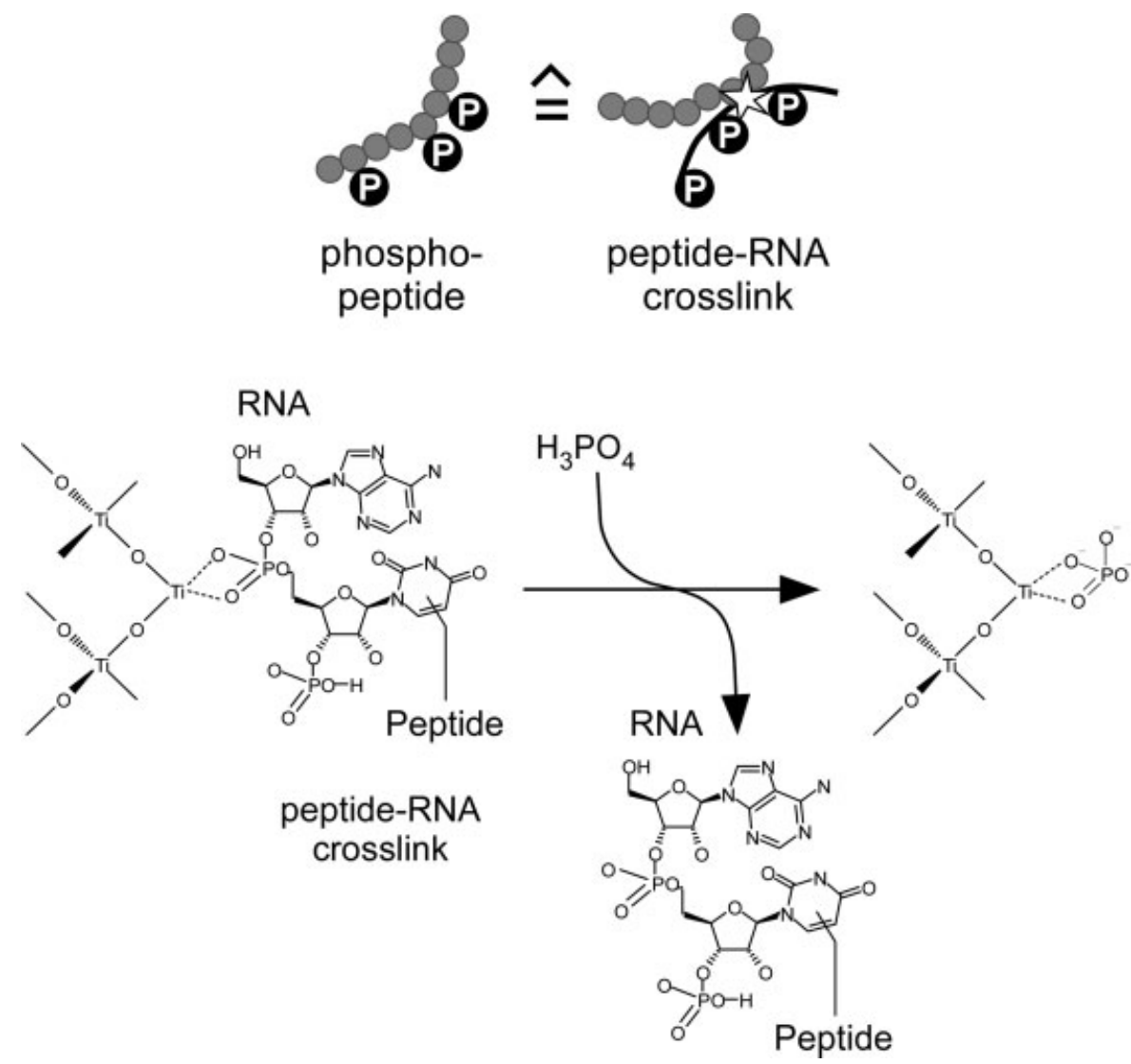

FIGURE 1 Purification strategy of peptide-RNA oligonucleotide crosslinks using $\mathrm{TiO}_{2}$ and inorganic phosphate for replacement of bound crosslinks. The purification took advantage of the fact that peptide-RNA crosslinks resemble phosphopeptides.

RNPs with endoproteinases as a first step to separate the peptides that are crosslinked to RNA from the great excess of noncrosslinked peptides. ${ }^{7-9}$ After hydrolysis of the RNA, peptide-linked oligonucleotides could be purified by microbore, capillary, or nano-reversed-phase (RP) high-pressure liquid chromatography (HPLC). For MS-based sequence determination, the conjugates were detected by (i) their absorbance at 220 and $254 \mathrm{~nm},{ }^{6}$ (ii) precursor-ion scanning combined with multiple reaction monitoring, ${ }^{10}$ or (iii) additional enrichment by immobilized metal affinity chromatography. ${ }^{5,11,12}$

Here, we report an automated enrichment strategy of peptide-RNA oligonucleotides derived from UV-irradiated and hydrolyzed snRNPs based on titanium dioxide $\left(\mathrm{TiO}_{2}\right)^{13}$ columns integrated within a $2 \mathrm{D}$ nano-LC system. The system avoids the separation of the noncrosslinked peptide moiety in the previous off-line SE step. $\mathrm{TiO}_{2}$ has been reported to be highly suitable for the enrichment of phosphopeptides as the copurification of acidic peptides is minimized in comparison with enrichment strategies using IMAC. ${ }^{14-16}$ Since phosphopeptides and peptide-RNA oligonucleotides share similar properties (i.e., the phosphate group) $\mathrm{TiO}_{2}$ should also prove useful in the enrichment of the latter species (Figure 1). Furthermore, $\mathrm{TiO}_{2}$ can be integrated into a HPLC system, whereas IMAC agarose beads do not withstand HPLC conditions. Accordingly, several systems have been set up for the on-line enrichment of phosphopeptides with $\mathrm{TiO}_{2}$ columns. $^{17-21}$

Our on-line enrichment strategy of peptide-RNA oligonucleotides from complex mixtures differs from the $\mathrm{TiO}_{2}$ on-line set-ups reported earlier, as it includes an additional desalting step. It combines two C18 trapping columns, a $\mathrm{TiO}_{2}$ enrichment column and a C18 nanoanalytical column. Enriched peptide-RNA oligonucleotides are spotted onto MALDI targets and analyzed by MALDI-ToF/ToF according to Kühn-Hölsken et al. ${ }^{6}$ In this feasibility study, we tested the system for the enrichment, detection, and sequencing of peptide-RNA crosslinks derived from UV-irradiated native U1 snRNPs and from the in vitro reconstituted $[15.5 \mathrm{~K}-61 \mathrm{~K}$ U4atac snRNP] complex; detection was performed without any further off-line chromatographic separation steps. Owing to the reduction in the number of experimental steps the loss of material is minimized. Moreover, this procedure 
makes possible the enrichment and subsequent analysis of phosphopeptides derived from noncrosslinked RNPs without a change in the set-up.

\section{RESULTS}

Loading, Washing, and Elution Conditions Suitable for $\mathrm{TiO}_{2}$ On-Line Chromatography Conditions for the Enrichment of Peptide-RNA Crosslinks and Phosphopeptides

We first established loading and elution conditions of crosslinks on $\mathrm{TiO}_{2}$ beads with the aim of finding conditions that can be used in a multidimensional chromatography set-up coupled to MALDI-ToF MS. Recent studies demonstrated that distinct loading, washing, and elution conditions are crucial for the successful enrichment of phosphopeptides using $\mathrm{TiO}_{2}{ }^{13,22}$ Loading in the presence of 2,5 dihydroxybenzoic acid (DHB) at a very low $\mathrm{pH}[5 \%$ trifluoroacetic acid (TFA)] has been shown to be optimal for the specific enrichment of phosphopeptides ${ }^{22}$ in an off-line approach. Washing was performed once with loading followed by a washing buffer, excluding DHB, and then phosphopeptides were eluted with $\mathrm{NH}_{4} \mathrm{OH}(25 \%, \mathrm{pH}$ 10.5). In alternative on-line approaches, phosphopeptides were readily eluted upon autosampler injection of $\mathrm{NH}_{4} \mathrm{OH}$ at $\mathrm{pH} 10.5 .^{20,21}$

However, these off-line and on-line conditions were-in our hands-not compatible with any nano-LC system that used standard RP materials and fused silica capillaries as flow connectors.

We thus tested suitable conditions for $\mathrm{TiO}_{2}$ enrichment that were more suitable for our purpose. We first used an offline (batch) system with an appropriate volume of $\mathrm{TiO}_{2}$ slurry. For these initial feasibility studies, we monitored the enrichment of phosphopeptides derived from the U1 snRNP specific protein $70 \mathrm{~K}$ after in-gel digestion ${ }^{23}$ under various elution conditions $[10 \mathrm{mg} / \mathrm{ml}$ methylphosphonic acid; $10 \mathrm{mg} / \mathrm{ml}$ glucoseamine-6-phosphate; $100 \mathrm{mM}$ ATP; $10 \mathrm{mg} / \mathrm{ml}$ $\left.\left(\mathrm{NH}_{4}\right)_{2} \mathrm{HPO}_{4}\right]$. In addition, we tested for the enrichment of a previously studied peptide-RNA crosslink derived from the U1 70K protein after UV irradiation of U1 snRNPs. For this purpose, U1 70K peptide-RNA oligonucleotide conjugates were isolated in a semipreparative manner by microbore HPLC fractionation as described by Kühn-Hölsken et al. ${ }^{6}$ Since these fractions still contain a large number of residual contaminating noncrosslinked peptides in addition to the actual crosslinked species, this serves as an ideal sample to test for enrichment and recovery of the crosslink. We also tested for the enrichment of that particular crosslink from a UV-irradiated U1 snRNP complex that was digested in solu- tion with RNases and endoproteinase and desalted with stage tips before $\mathrm{TiO}_{2}$ enrichment.

We found that best results were obtained by loading the sample in 50\% (v/v) acetonitrile (ACN) and 0.25\% (v/v) TFA in water, stepwise washing with 25 and $50 \%(\mathrm{v} / \mathrm{v}) \mathrm{ACN} / 0.25 \%$ $(\mathrm{v} / \mathrm{v})$ TFA in water and final elution of the phosphopeptides and crosslinks in $10 \mathrm{mg} / \mathrm{ml}\left(\mathrm{NH}_{4}\right)_{2} \mathrm{HPO}_{4} \mathrm{pH} 1.1$ in water combined with a subsequent desalting step using stage tips. ${ }^{24}$ We observed satisfactory enrichment and detection of a U1 70K phosphopeptide (YDERPGPpSPLPHR, data not shown) and the $\mathrm{U} 170 \mathrm{~K}$ crosslink (RVLVDVER to an AU dinucleotide to an AUCAC pentanucleotide, Figures $2 \mathrm{~A}$ and $2 \mathrm{~B}$ ).

It has been reported that $\mathrm{TiO}_{2}$ has certain disadvantages in the enrichment of multiply phosphorylated or very hydrophilic species (e.g., short tryptic fragments), as the former bind strongly, and the latter fail to bind at all, to the $\mathrm{TiO}_{2}$ matrix. ${ }^{16}$ However, we do not observe a similar effect upon the enrichment of the U1 70K peptide-RNA crosslink. Although the $70 \mathrm{~K}$ peptide that is crosslinked to a dinucleotide (AU) is eluted more efficiently when its signal intensity is compared to those of the other crosslinks before and after enrichment, crosslinks carrying three, four, and five nucleotides are eluted equally well from the $\mathrm{TiO}_{2}$ material (Figures $2 \mathrm{~A}$ and $2 \mathrm{~B}$ ). Therefore, the intensity of the shorter oligonucleotide modified peptides is relatively increased as compared to the nonenriched HPLC fraction. In the same manner, it was possible to enrich the 70K specific peptide RVLVDVER crosslinked to an di- and trinucleotide from the crude mixture of in-solution digested UV-irradiated U1 snRNPs, demonstrating the capacity in the removal of the background (Figures $2 \mathrm{C}$ and $2 \mathrm{D}$ ). We conclude that for the successful enrichment of the crosslinked species from a crude mixture, i.e., a completely hydrolyzed RNP, the (crosslinked) RNA moiety should be as small as possible which can be achieved by digestion of the RNA with a mixture of RNase A, T1, and benzonase.

\section{D Chromatographic Setup}

The conditions for loading, washing, and elution to enrich peptide-RNA crosslinks are integrated into our multidimensional chromatographic set-up by using $\mathrm{TiO}_{2}$ columns packed in our laboratory. Figure 3 shows the assembly of the different columns mounted into the chromatography system equipped with two 10-port nanovalves, and it illustrates the individual chromatographic steps. U1 snRNP and reconstituted [15.5K-61K-U4 snRNA] complex ${ }^{25,26}$ were hydrolyzed with ribonucleases (RNase A, T1, and benzonase) and endoproteinases (trypsin or chymotrypsin).

The crude mixture of noncrosslinked and crosslinked peptides, phosphorylated peptides, and noncrosslinked RNA oli- 

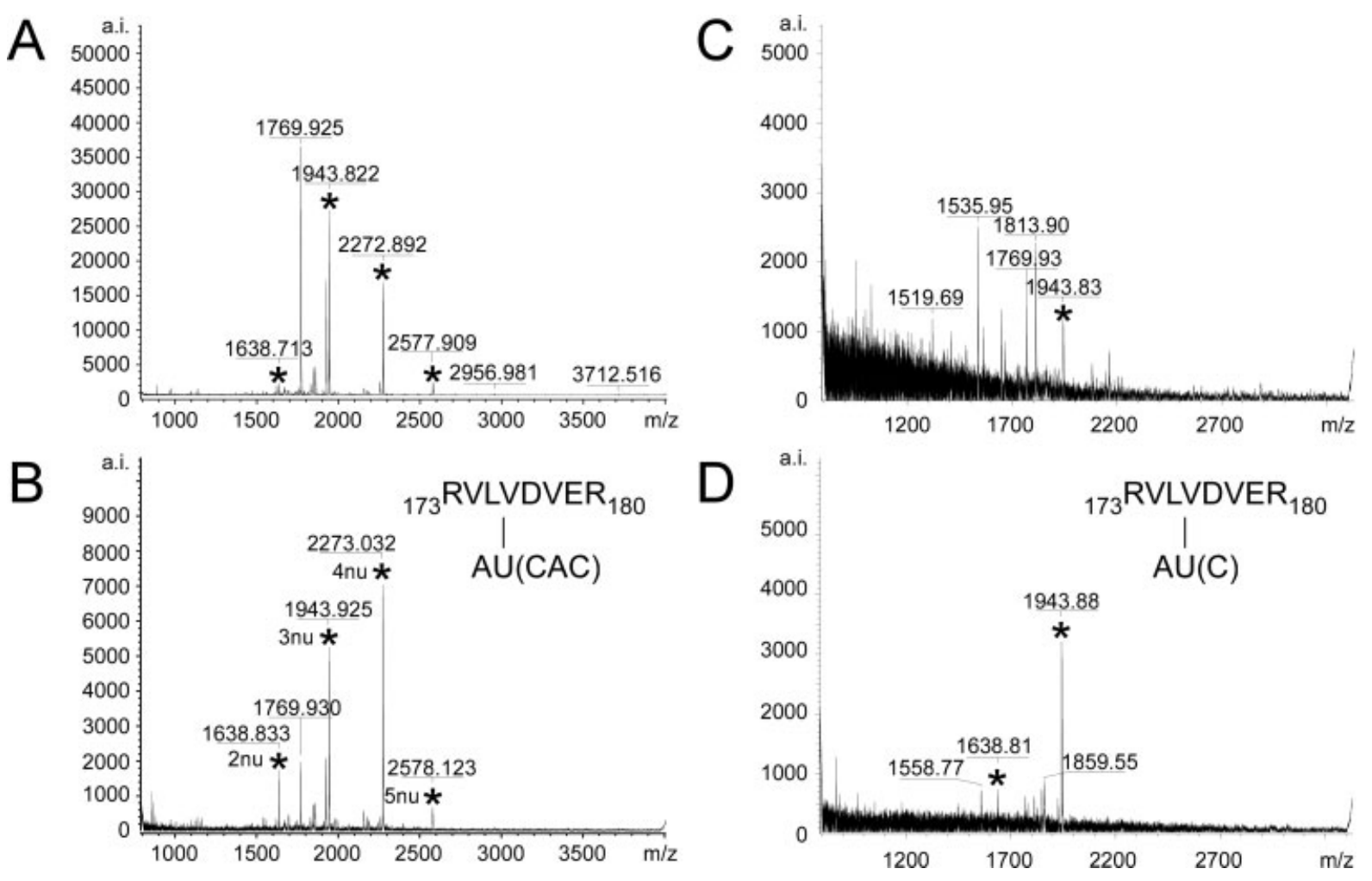

FIGURE 2 Test for appropriate loading, washing, and elution conditions for enrichment of peptide-RNA crosslinks on $\mathrm{TiO}_{2}$ beads using liquid chromatography (LC)-compatible solvents. A: MALDI peptide mass fingerprint of a capillary RP-HPLC fraction containing semipreparatively purified U1 70K peptide RVLVDVER (positions 173 to 180 ) crosslinked to AU ( $m / z=1638.713$ ), AUC $(m / z=1943.822)$, AUCA $(m / z=2272.892)$, and to AUCAC $(m / z=2577.909)$. Crosslinks are marked with an asterisk. The sequence of the crosslinked peptide and RNA was determined by MSMS analysis (see Figure 6). B: MALDI peptide mass fingerprint of the same fraction after enrichment of the crosslinks with $\mathrm{TiO}_{2}$. The number of nucleotides of the crosslinked RNA moiety is listed within the spectrum. C: MALDI peptide mass fingerprint of UV-irradiated U1 snRNPs that were completely hydrolyzed with RNases and endoproteinase trypsin and desalted before analysis. D: MALDI peptide mass fingerprint of UV-irradiated U1 snRNPs that were completely hydrolyzed with RNases and endoproteinase trypsin and putative crosslinks being enriched with $\mathrm{TiO}_{2}$ subsequent to the desalting of the sample before analysis.

gonucleotides is injected onto the first trapping column $(\mathrm{C} 18$ Vydac, $10 \mathrm{~mm} \times 0.15 \mathrm{~mm})$ in the presence of $3.5 \%(\mathrm{v} / \mathrm{v})$ $\mathrm{ACN}, 0.1 \% \mathrm{TFA}$ in water at a flow rate of $5 \mu \mathrm{l} / \mathrm{min}$ for $25 \mathrm{~min}$. Under these conditions the vast majority of the RNA oligonucleotides does not bind to the trapping column and is discarded into the waste. Noncrosslinked and crosslinked peptides bind to the $\mathrm{C} 18$ trapping column mounted between the two 10-port valves (Figures $3 \mathrm{~A}$ and $3 \mathrm{~B}$ ). After the two valves were switched from position 1-10 and 1-2 to 1-2 and $1-10$, respectively, the nanopump elutes the bound species from the $\mathrm{C} 18$ trapping column by applying a gradient from 8 to $48 \%(\mathrm{v} / \mathrm{v}) \mathrm{ACN}$ (10 to $60 \%$ solvent $\mathrm{B}_{1}$ ), $0.25 \%(\mathrm{v} / \mathrm{v})$ TFA in water in $120 \mathrm{~min}$ with a flow rate of $300 \mathrm{nl} / \mathrm{min}$. Under these conditions, species that carry a phosphate moiety (i.e., phosphorylated peptides and peptide-linked RNA oligonucleotides) are bound effectively to the $\mathrm{TiO}_{2}$ column (equilibrated with $48 \% \mathrm{ACN}, 0.25 \%$ TFA in water at a flow rate of $3.5 \mu \mathrm{l} / \mathrm{min}$ ), whereas most of the noncrosslinked and nonmodified species do not bind and are subsequently eluted and separated on the C18 analytical nanocolumn (Vydac $5 \mu \mathrm{m}$ particle size, $300 \AA$ A pore width, $120 \mathrm{~mm} \times 0.075 \mathrm{~mm}$, Figures $3 \mathrm{C}$ and $3 \mathrm{D}$ ) and analyzed by MALDI-MSMS.

Peptides eluted from the analytical column were mixed with $2,5-\mathrm{DHB}(10 \mathrm{mg} / \mathrm{ml}$ in $20 \%(\mathrm{v} / \mathrm{v})$ ACN, $0.1 \%(\mathrm{v} / \mathrm{v})$ $\mathrm{H}_{3} \mathrm{PO}_{4}$ ) and were spotted every $30 \mathrm{~s}$ onto a MALDI stainless steel target and peptides in the spot fractions were analyzed by automated MS and MSMS on a 4800 MALDI-ToF/ToF instrument (Sciex Applied Biosystems) or spotted onto a 


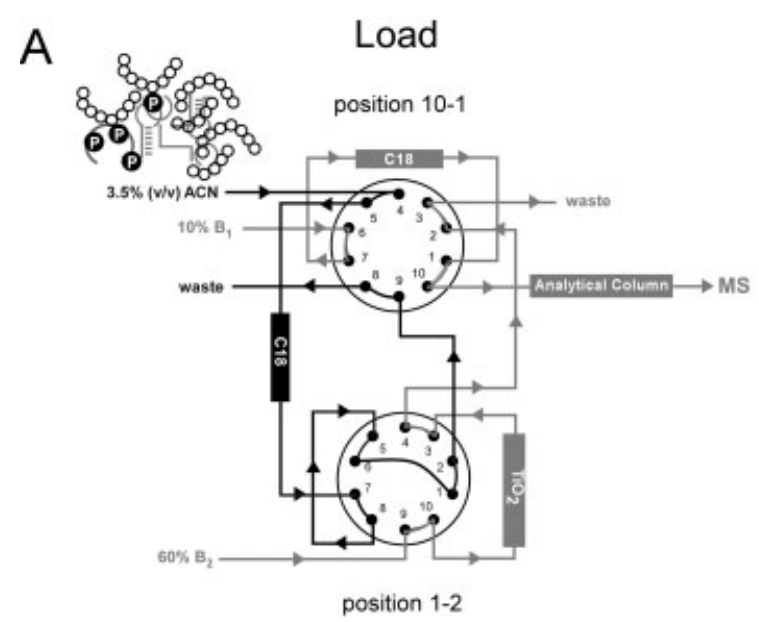

B

Bind

C

Bind/Flow through

position 1-2

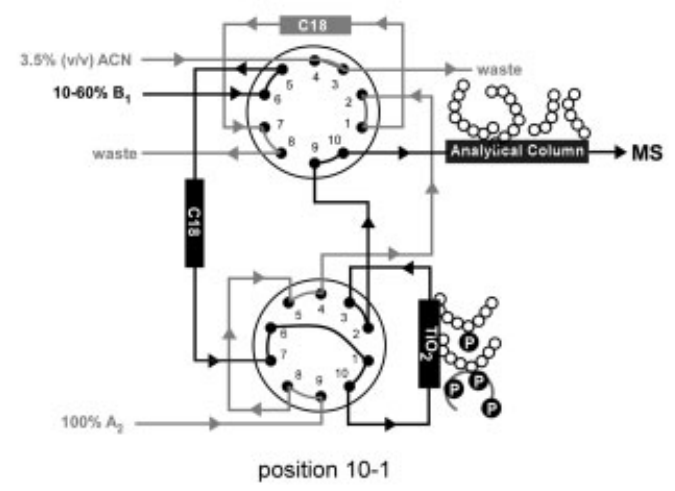

$E$

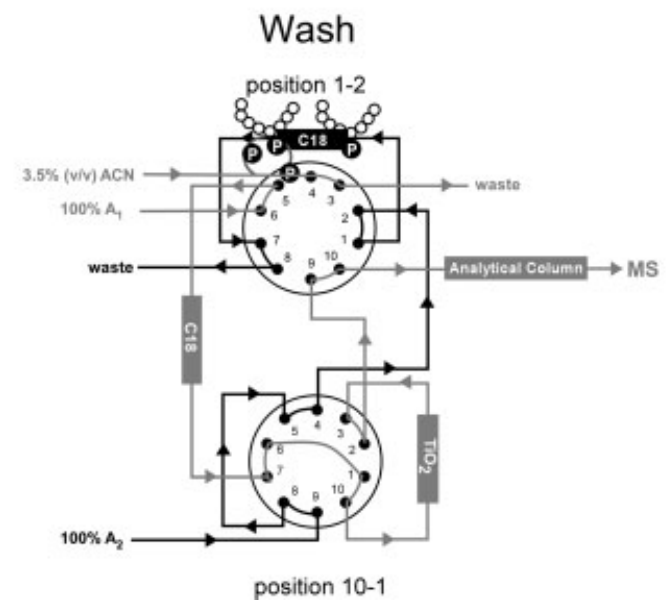

$\mathrm{F}$

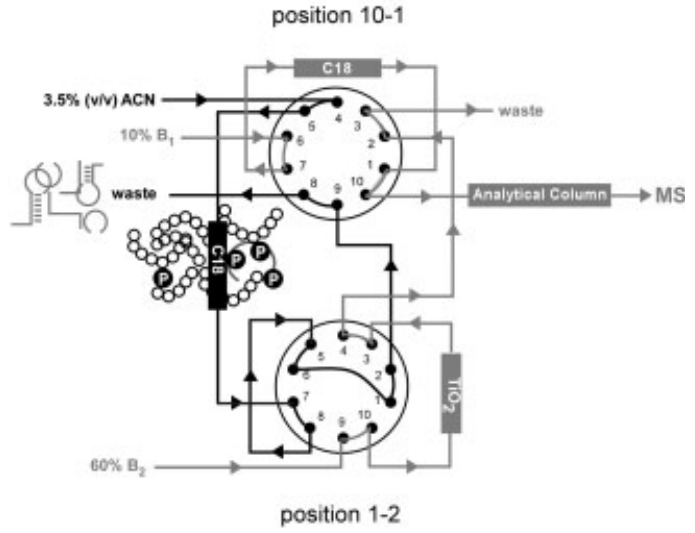

D

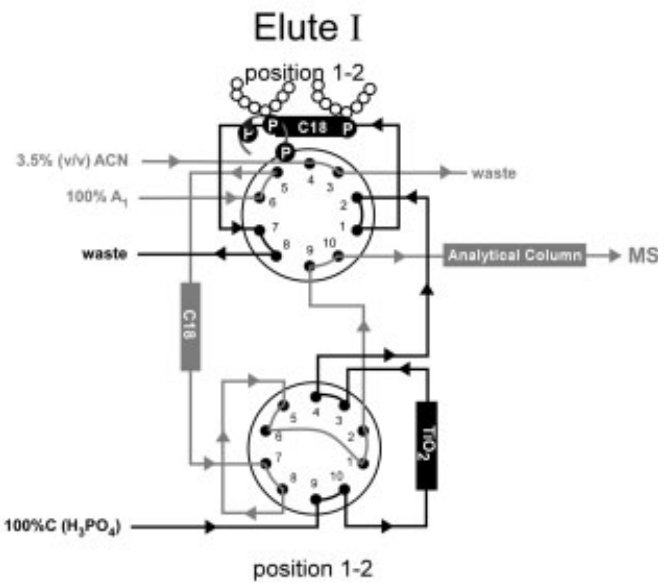

\section{Elute II}

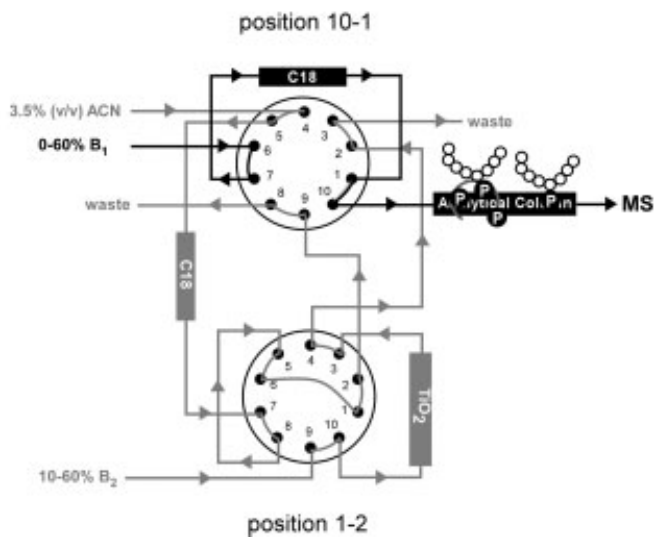

FIGURE 3 Schematic overview of 2D chromatography setup in the different 10-port valve positions during automated simultaneous enrichment of phosphopeptides and peptide-RNA crosslinked derived from (UV-irradiated) protein-RNA complexes after complete hydrolysis of the protein and RNA moieties. Active connections and pumps with the applied solvents in the respective steps of the chromatography are shown in black, those that not used are in gray. A: Loading of the crude mixture onto the first C18 precolumn. B: Binding of phosphopeptides, crosslinked peptideRNA oligonucleotides, and the excess of noncrosslinked peptides to the first C18 precolumn and elution of the excess of noncrosslinked RNA oligonucleotides from the system (into the waste). C: Elution of the trapped mixture from the first C18 precolumn, and binding of phosphopeptides and peptide-RNA crosslinks to the $\mathrm{TiO}_{2}$ column. Nonphosphorylated and noncrosslinked peptides did not bind and were separated by the nanoanalytical column and subsequently analyzed by MS. D: Elution of bound phosphopeptides and crosslinks from the $\mathrm{TiO}_{2}$ column onto the second $\mathrm{C} 18$ precolumn for desalting. E: Washing of the phosphopeptides and crosslinks on the C18 precolumn. F: Elution of the phosphopeptides from the C18 desalting column onto the nanoanalytical column for subsequent separation and analysis in the mass spectrometer. 
A

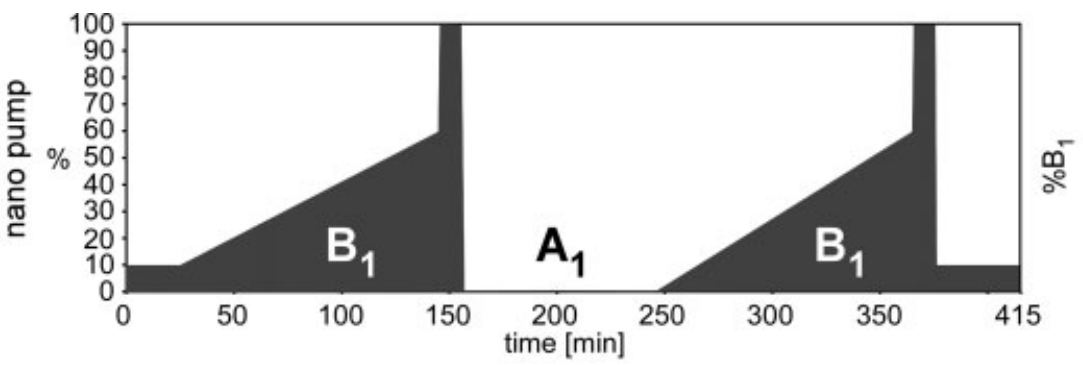

B

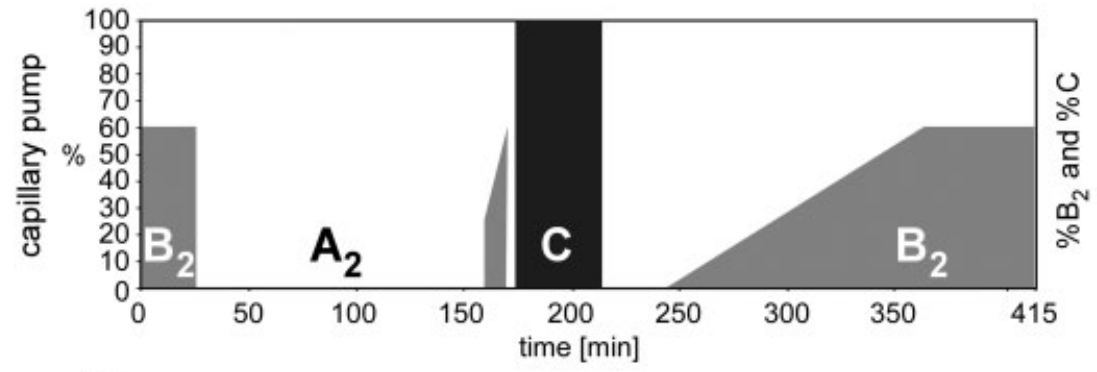

C
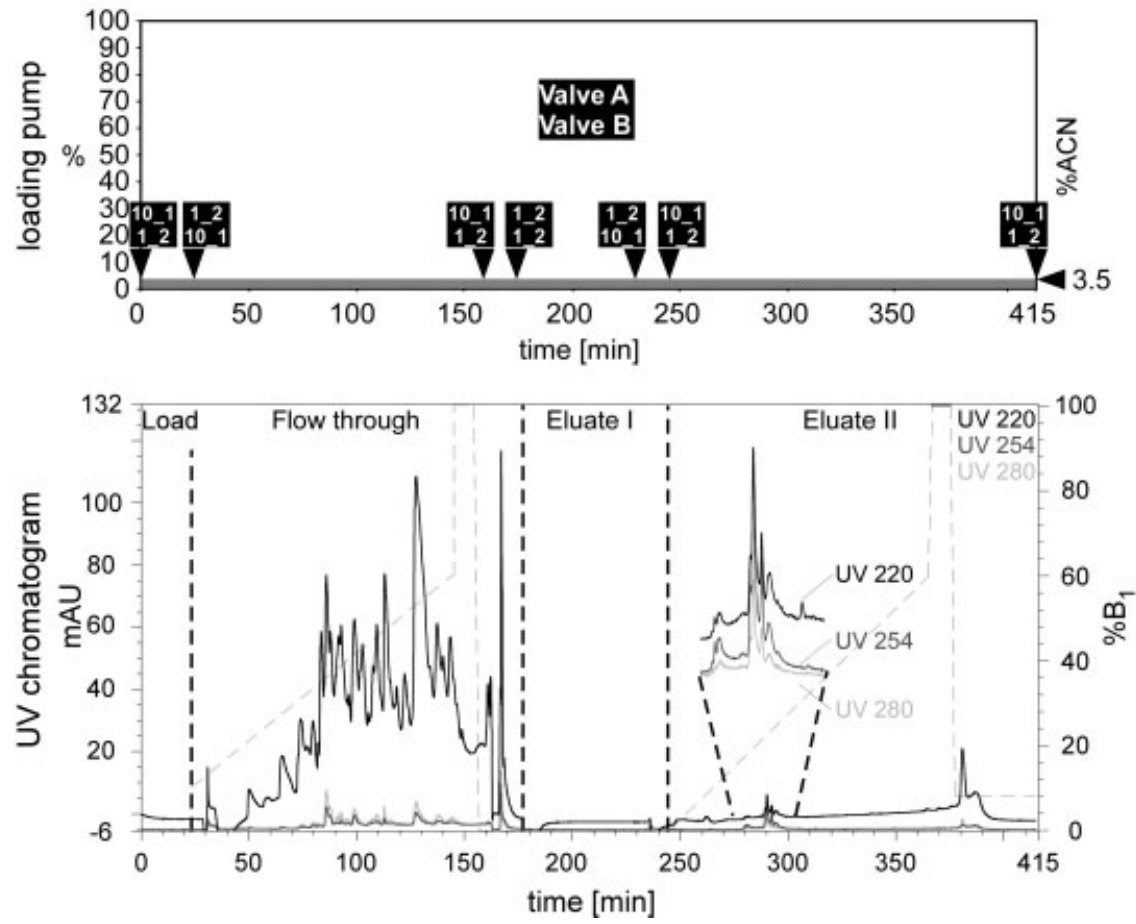

FIGURE 4 Applied gradients of the nano, capillary, and loading pumps during 2D chromatography including time points of switching of the 10-port valves. The elution profiles were monitored by the connected UV detector. The overall time of separation was $415 \mathrm{~min}$. A: Gradients generated by nanopump at $300 \mathrm{nl} / \mathrm{min}$ flow rate for elution of the nonphosphorylated and noncrosslinked species from 25 to $145 \mathrm{~min}$ (flow-through) and for elution of the phosphorylated and crosslinked species between 245 and 365 min (elution II). Solvent $A_{1}$ was $0.25 \%$ (v/v) TFA and solvent $B_{1}$ was $80 \%$ $(\mathrm{v} / \mathrm{v})$ ACN, $0.25 \%(\mathrm{v} / \mathrm{v})$ TFA. B: Applied solvents and gradients of the capillary pump for equilibration of the $\mathrm{TiO}_{2}$ column and washing and elution of the bound species on and from the $\mathrm{TiO}_{2}$ column (Eluate I), respectively using solvents $A_{2}$ and $B_{2}$ (see $A_{1}$ and $B_{1}$ ) and $C$. The flow rate was $3.5 \mu \mathrm{l} / \mathrm{min}$. $\mathrm{A}_{2}$ was used to equilibrate the second $\mathrm{C} 18$ precolumn and subsequently desalt the bound phosphopeptides on the second C18 precolumn. C: Isocratic profile of the loading column. The switches of the two 10-port valves at various time points are indicated. D: UV chromatogram of the eluate in the different 2D separation steps. The dashed line indicates the applied gradients for separation of noncrosslinked peptide moiety (flow-through) and the crosslinked species (Eluate II). 
Bruker anchor chip and analyzed on a Bruker Reflex IV. Alternatively, LC-separated peptides were mixed with $\alpha$ cyano-4-hydroxy-cinnamic acid ( $\alpha$-cyano, $10 \mathrm{mg} / \mathrm{ml}$ in $70 \%$ $(\mathrm{v} / \mathrm{v}) \mathrm{ACN}, 0.1 \%(\mathrm{v} / \mathrm{v}) \mathrm{TFA})$ and collected onto stainless steel MALDI targets suitable for automated MS and MSMS analysis on a 4800 MALDI-ToF/ToF instrument. After switching of Valve 2 to Position 1-2, the $\mathrm{TiO}_{2}$ column is washed according to the procedures in our off-line batch experiments with a gradient of 20-48\% (v/v) ACN, 0.25\% (v/v) TFA in water that is delivered by the capillary pump (channels $A_{2}$ and $B_{2}$ at a flow rate of $3.5 \mu \mathrm{l} / \mathrm{min}$ ). Peptides bound to the $\mathrm{TiO}_{2}$ column were eluted by the third channel of the capillary pump with solvent $\mathrm{C}\left(10 \mathrm{mg} / \mathrm{ml}\left(\mathrm{NH}_{4}\right)_{2} \mathrm{HPO}_{4} \mathrm{pH}\right.$ 1.1 in water) at a flow rate of $3.5 \mu \mathrm{l} / \mathrm{min}$ onto the second trapping column mounted at Valve 1 (Figure 3D). This trapping column contains ReproSil-Pur Basic C18-HD (5 $\mu \mathrm{m}$, Dr. Maisch $\mathrm{GmbH}$ ) combining a small particle diameter with similar binding properties as Oligo R3 material (Applied Biosystems) which has been shown to be most suitable for the desalting of enriched phosphopeptides before MS analysis. ${ }^{27}$ After switching Valve 2 back into position 10-1 bound phosphopeptides and crosslinks are washed with solvent $\mathrm{A}_{2}$ [0.25\% (v/v) TFA in water] delivered at a flow rate of $3.5 \mu \mathrm{l} /$ min by the capillary pump (Channels 1 and 2) for $30 \mathrm{~min}$
(Figure 3E). After switching Valve 2 back to Position 1-2 and Valve 1 to Position 10-1, phosphopeptides and crosslinks are eluted from the trapping column and separated on the analytical column with a gradient from 0 to $48 \%(\mathrm{v} / \mathrm{v}) \mathrm{ACN}$, $0.25 \%(\mathrm{v} / \mathrm{v})$ TFA in water in $120 \mathrm{~min}$ at a flow rate $300 \mathrm{nl} /$ min. The $\mathrm{TiO}_{2}$ column is re-equilibrated by the capillary pump for the next sample by applying a gradient of 0 to $48 \%$ $(\mathrm{v} / \mathrm{v}) \mathrm{ACN}, 0.25 \%(\mathrm{v} / \mathrm{v}) \mathrm{TFA}$ in water in $120 \mathrm{~min}$ at a flow rate of $3.5 \mu \mathrm{l} / \mathrm{min}$. The phosphopeptides and crosslinked species eluted are mixed with 2,5-DHB as matrix and are spotted every $30 \mathrm{~s}$ onto a MALDI target. Spots were analyzed by MALDI MS and MSMS. In those fragment spectra that show a loss of $\mathrm{H}_{3} \mathrm{PO}_{4}$ (98 a.m.u.) the corresponding precursors are considered to be phosphopeptides or peptide-RNA crosslinks and are reanalyzed manually by MSMS.

Figure 4 summarizes the solvent gradients applied to the nanopump for separation of the nonmodified peptides and modified peptides (Figure 4A), to the capillary pump for washing and elution of the crosslinks on and from the $\mathrm{TiO}_{2}$ column (Figure 4B) and to the loading pump for loading the sample including applied switches of the valves (Figure 4C). Figure $4 \mathrm{D}$ shows the elution profile of the first gradient for the separation of the noncrosslinked species (25-145 min) and the second gradient for the separation of the crosslinked
A

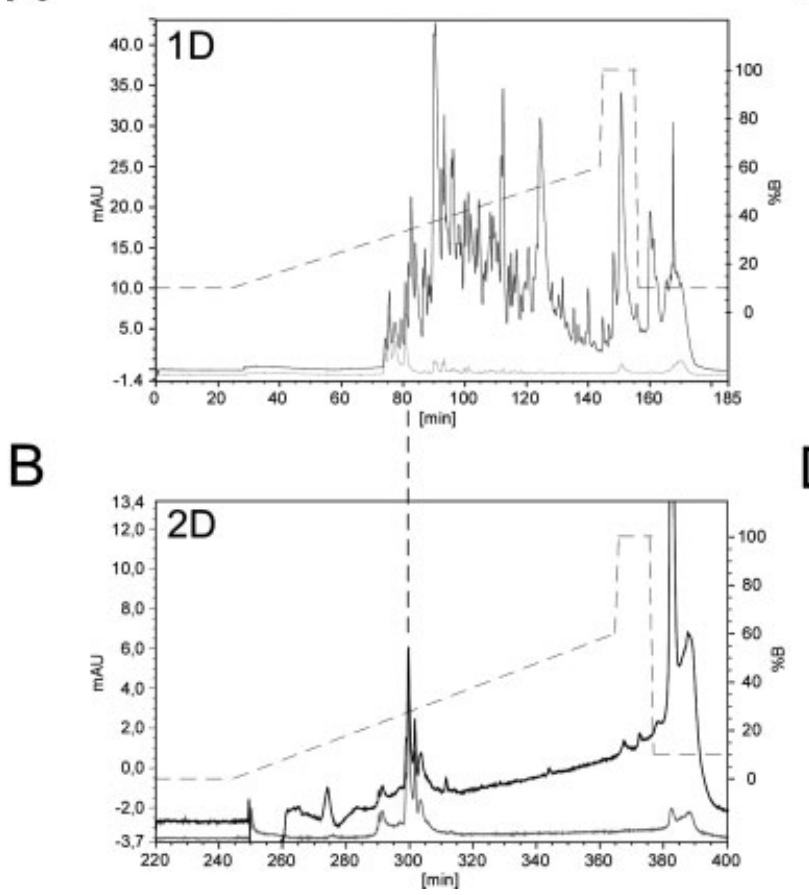

crosslinked [61K-15.5K-U4atac]

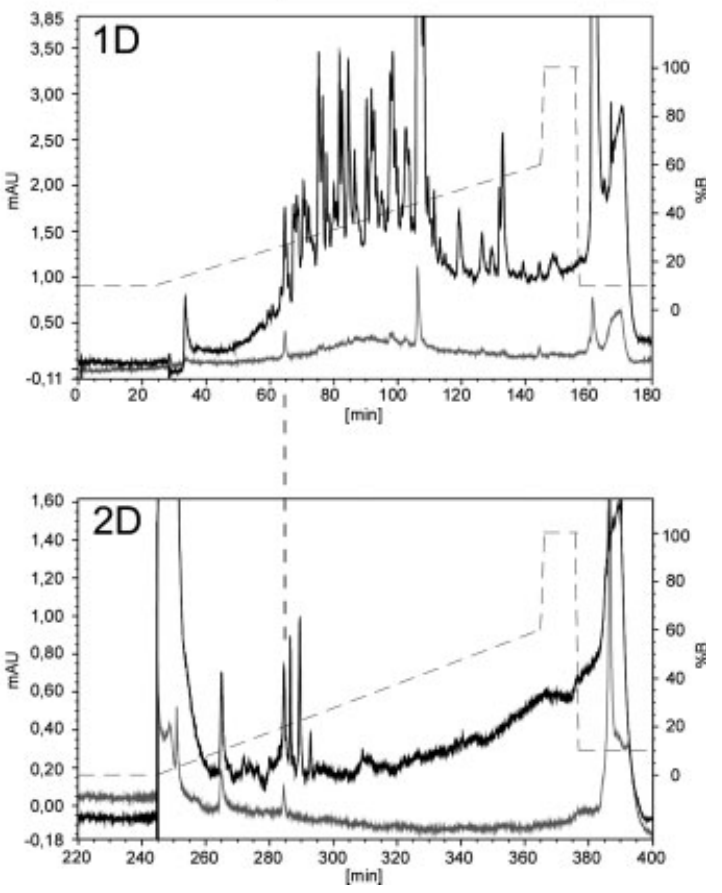

FIGURE 5 Comparison of standard 1D (A and C) and 2D chromatography (B and D) in the separation of crosslinked peptide-RNA oligonucleotide conjugates derived from UV-irradiated U1 snRNP and [15.5K-61K-U4atac snRNA] hydrolyzed with RNases and endoproteinases. 
A

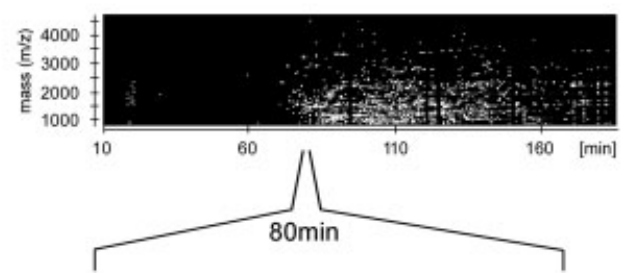

C

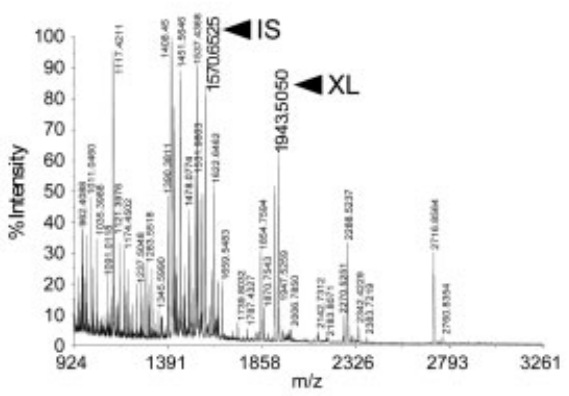

B

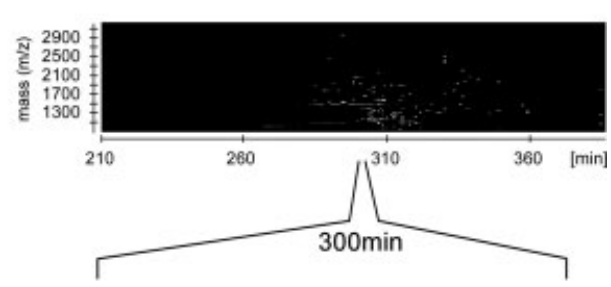

$D$

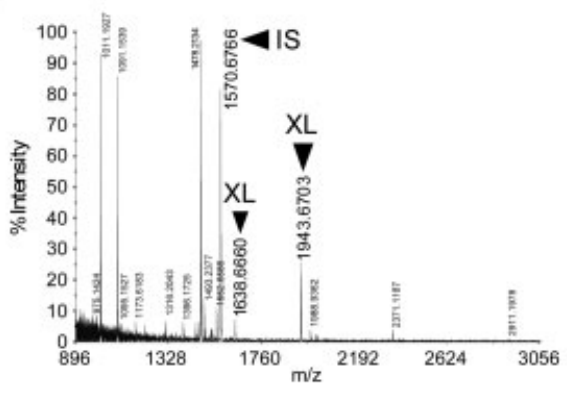

$E$
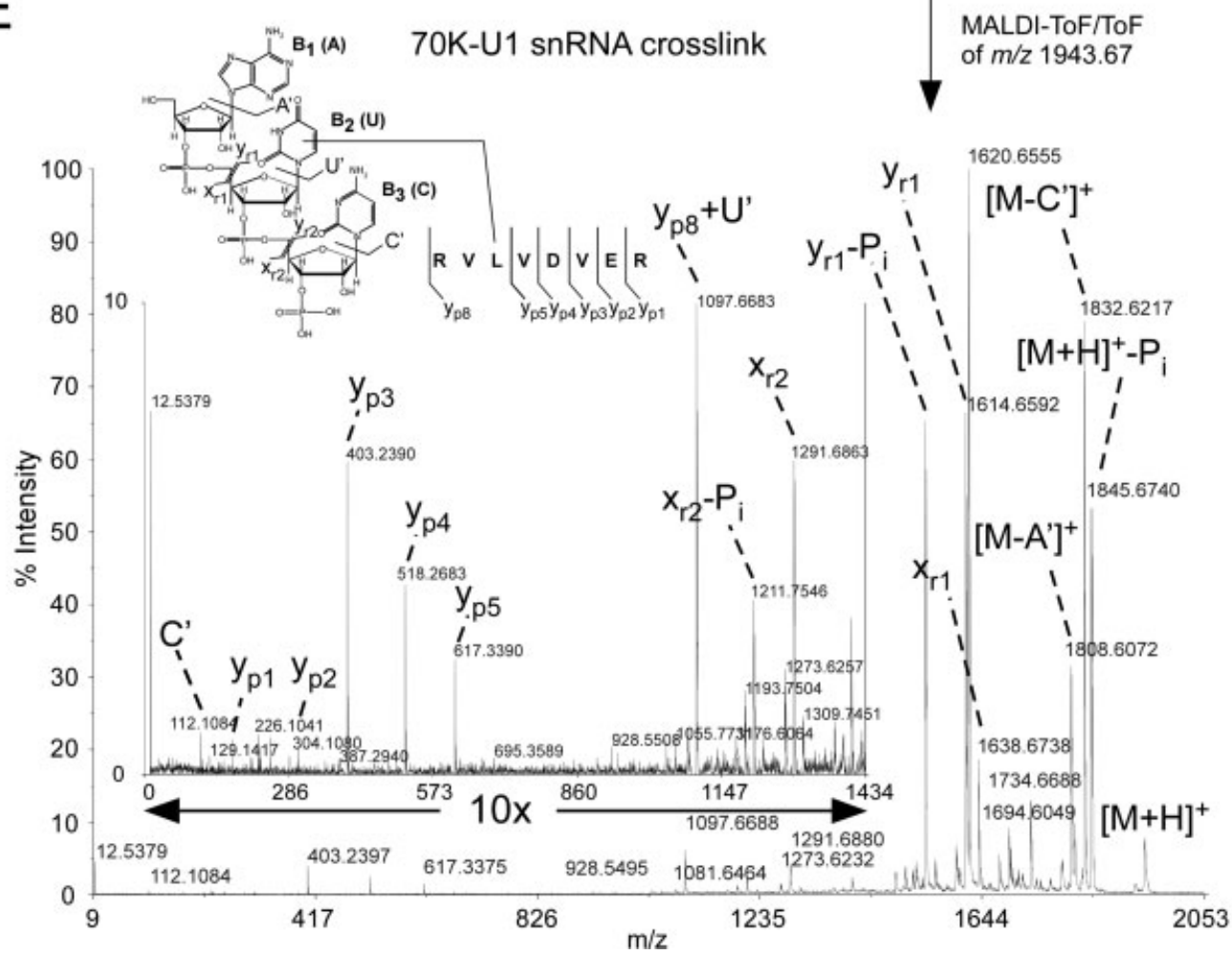

FIGURE 6 MALDI MS and MSMS analysis of enriched crosslinked peptide-RNA oligonuclotides derived from UV-irradiated U1 snRNPs hydrolyzed with RNases and endoproteinase. A and B: "Heat maps" of the 1D separation and the Eluate II fraction of the 2D separated mixture, respectively. C and D: Automated MALDI MS spectra recorded at the elution time $80 \mathrm{~min}(\sim 21 \% \mathrm{ACN})$ and $300 \mathrm{~min}(\sim 21 \% \mathrm{ACN})$ of the $1 \mathrm{D}$ and 2D separation; IS marks the spiked internal [Glu1]-Fibrinopeptide B standard. E: MALDI MSMS spectrum of the enriched crosslink precursor $(\mathrm{m} / \mathrm{z}=$ 1943.67). Y-type ion series of the peptide moiety $\left(y_{p}\right)$ and the $y$ - and $x$-type ion series of the RNA moiety $\left(\mathrm{y}_{\mathrm{r}}\right.$ and $\left.\mathrm{x}_{\mathrm{r}}\right)$ are indicated as well as the observed base and phosphate losses $\left(\mathrm{A}^{\prime}, \mathrm{U}^{\prime}, \mathrm{C}^{\prime}, \mathrm{P}_{\mathrm{i}}\right)$. The entire sequence of the crosslinked peptide and the RNA moiety with the observed fragment ions is shown in the spectrum. 
peptides (245-365 $\mathrm{min})$. As indicated by the multichannel absorption at 220, 254, and $280 \mathrm{~nm}$, the RNA-containing species were exclusively detected and sequenced in the elution profile of the enriched species, whereas at the corresponding ACN concentration in the first elution gradient, no dual absorption of the crosslinks was detectable (Figure 4D).

\section{Enrichment of Peptide-RNA Oligonucleotide} Crosslinks from UV-Irradiated Native U1 snRNPs and Reconstituted

\section{[15.5K-61K-U4atac snRNA] Complexes}

We next compared our 2D setup with conventional 1D nanoreversed phase (RP) setup. Therefore, we used native U1
A

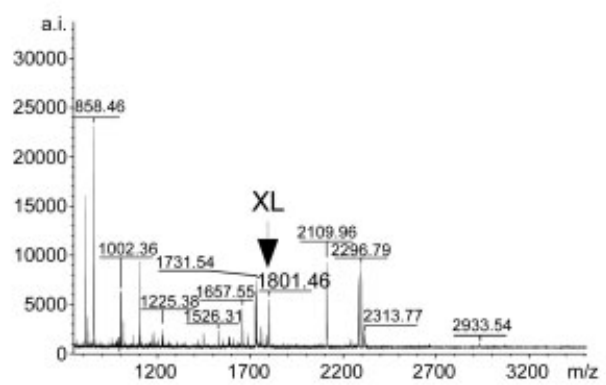

B

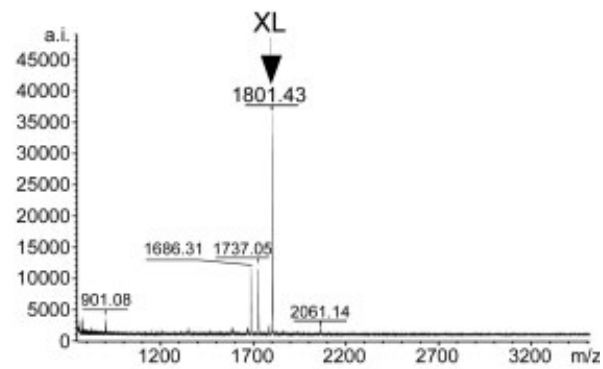

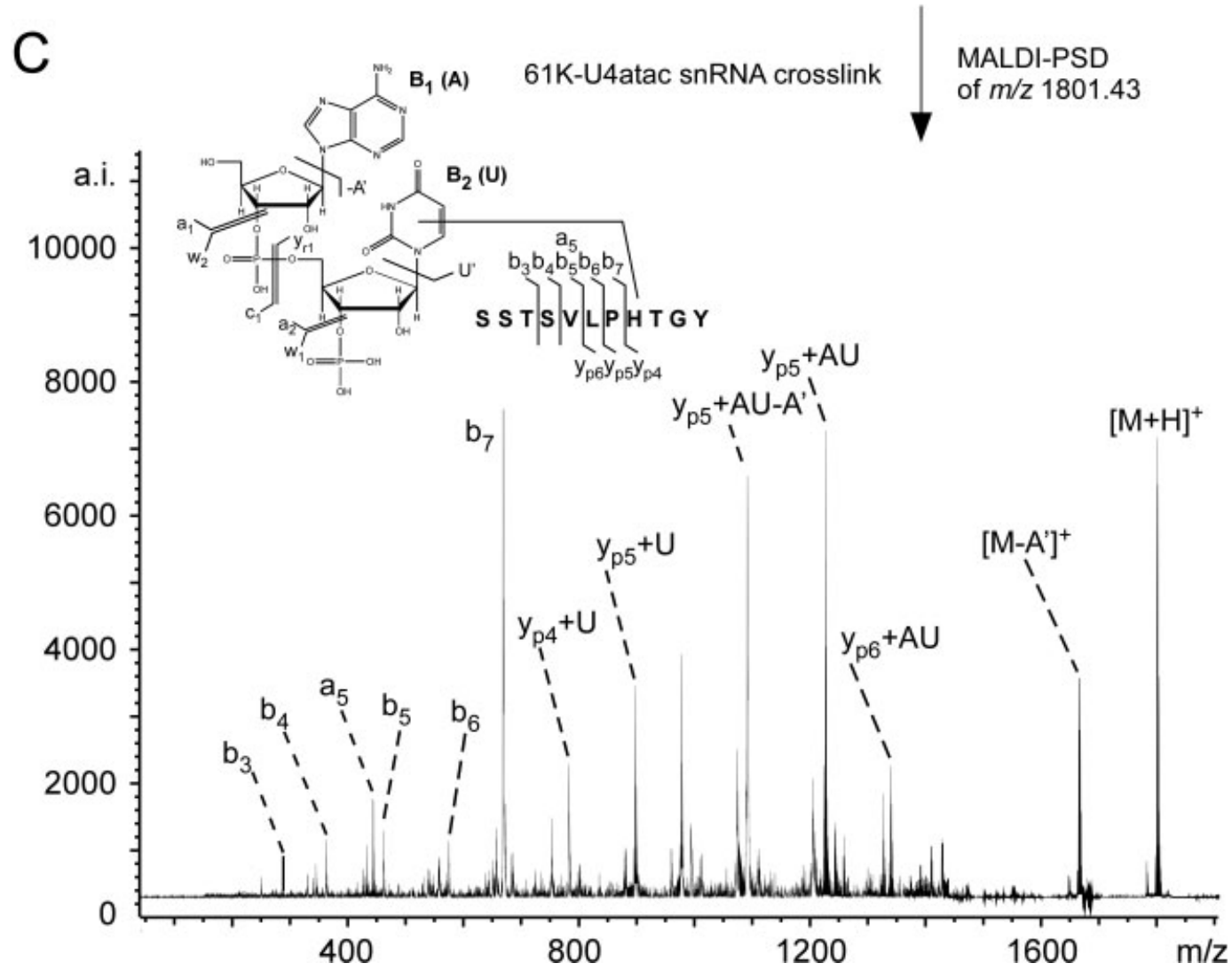

FIGURE 7 MALDI MS and MSMS analysis of enriched crosslinked peptide-RNA oligonuclotides derived from UV-irradiated U1 snRNP and [15.5K-61K-U4atac snRNA] hydrolyzed with RNases and endoproteinase chymotrypsin. A and B: MALDI MS spectra of 1D and 2D fraction at $\sim 16 \%$ ACN containing putatively crosslinked species $(m / z=1801.43)$. C: MSMS (PSD) spectrum of the enriched precursor $m / z=1801.43$. The spectrum reveals the crosslinked peptide sequenced derived from the $61 \mathrm{~K}(\mathrm{hPrP} 31)$ protein crosslinked to an AU dinucleotide. Fragment ions of the crosslinked peptide and RNA sequence are depicted within the spectrum and the sequences. Y-type ion series of the peptide moiety $\left(\mathrm{y}_{\mathrm{p}}\right)$ and the $\mathrm{y}$ - and $\mathrm{x}$-type ion series of the RNA moiety $\left(\mathrm{y}_{\mathrm{r}}\right.$ and $\left.\mathrm{x}_{\mathrm{r}}\right)$ are indicated as well as the observed base and phosphate losses $\left(\mathrm{A}^{\prime}, \mathrm{U}^{\prime}, \mathrm{C}^{\prime}, \mathrm{P}_{\mathrm{i}}\right)$. 
snRNPs and reconstituted [15.5K-61K-U4atac snRNA] complexes and irradiated them at $254 \mathrm{~nm}$ according to Nottrott et al. ${ }^{25,26}$ After dissociation of the complexes in the presence of urea, the RNA moiety was digested with RNase A, T1, and benzonase to generate RNA oligonucleotides that were as small as possible (see above). The protein moiety was hydrolyzed with trypsin or chymotrypsin, respectively, and the crude mixture was applied onto the $2 \mathrm{D}$ chromatographic system. In parallel experiments we injected the mixture onto a "standard" nano-LC system equipped with a precolumn for desalting of the sample, working in back-flush mode. Figures $5 \mathrm{~A}$ and $5 \mathrm{~B}$ show the elution profile of the standard 1D separation and the final elution step in the $2 \mathrm{D}$ enrichment, respectively, of completely hydrolyzed U1 snRNPs after UV irradiation. Figures 5C and 5D show the respective elution profiles from completely hydrolyzed [15.5K-61K-U4atac snRNA] after UV irradiation. As expected, the elution profile of the standard 1D gradient is much more complex as compared to the 2D separation. Nonetheless, by monitoring the absorbance at 214 and $254 \mathrm{~nm}$, putative crosslinks were also detected at lower concentration of ACN (apparent at $21 \%$ or $16 \% \mathrm{ACN}$ in the chromatogram). In the $2 \mathrm{D}$ elution profile these putative crosslinks represent almost the only peaks that were detectable, especially in the U1 snRNP sample.

We analyzed the spotted fractions of the both gradients (1D and 2D) by MALDI MS and MSMS for the enrichment of peptide-RNA crosslinks (Figures 6 and 7). Figures $6 \mathrm{~A}$ and $6 \mathrm{~B}$ show the $2 \mathrm{D}$ heat maps of the eluted species in the $1 \mathrm{D}$ and 2D separation of the crosslinked U1 snRNP, respectively. The complexity was dramatically reduced by the enrichment step. MALDI MS spectra were recorded at corresponding elution times $(\sim 21 \% \mathrm{ACN})$ containing the $\mathrm{U} 170 \mathrm{~K}$ specific peptide RVLVDVER crosslinked to a di or trinucleotide. The high complexity of the fraction before the enrichment did not reveal the putatively detectable peptide-RNA crosslinks. As the total sample amount per spot is not enough to select more than 10 precursors for extensive MALDI-MSMS analysis we could not obtain sequence information for all precursors present in the fraction. Consequently, the low-abundance crosslinks were not automatically selected and sequenced. In contrast, corresponding fractions in the 2D separation show significantly less complexity, and putative crosslinked peptide-RNA oligonucleotides derived from U1 snRNP complexes are clearly enriched (Figures 6C and 6D). The MALDI-MSMS spectrum from the precursor $\mathrm{m} / \mathrm{z}=$ 1943.67 revealed sufficient sequence information on the crosslinked RNA and peptide moiety for unambiguous identification (Figure 6E). As expected from MALDI analysis, we observed a strong neutral loss ( -98 a.m.u.) revealing a crosslinked RNA moiety. By annotation of the observed fragment ions, the sequence of the crosslinked peptide was deduced to be VDVER. The further detected loss of an adenine base (135 a.m.u.), cytosine base (112 a.m.u.), cytidine (305 a.m.u.), and adenosine (329 a.m.u.) confirm the crosslink to be the U1 70K peptide RVLVDVER, crosslinked to an AUC trinucleotide (Figure 6E). One other enriched precursor in the shown fraction (Figure 6D) was RVLVDVER crosslinked to $\mathrm{AU}(\mathrm{m} / z=1638.68)$.

Figures 7A and 7B show fractions of the $1 \mathrm{D}$ and $2 \mathrm{D}$ separation, respectively, of completely hydrolyzed UV-irradiated [15.5K-61K-U4atac snRNA] complexes eluting at $\sim 16 \%$. In the corresponding $2 \mathrm{D}$ fraction, the putative crosslink at $m / z=1801.43$ is clearly enriched. MSMS experiments identified this enriched species being a chymotryptic peptide derived from the U4-specific 61K (hPrp31) protein crosslinked to an AU dinucleotide (SSTSVLPHTGY to AU, Figure 7C).

\section{CONCLUSIONS}

We report here the efficient on-line capturing and recovery of peptide-RNA crosslinks after total hydrolysis of UV-irradiated protein-RNA complexes. For this purpose we introduced a novel $2 \mathrm{D}$ chromatographic approach using $\mathrm{TiO}_{2} \mathrm{col}-$ umns for the enrichment of the crosslinked species. In contrast to our previous studies, the set-up has enabled us to isolate peptide-RNA oligonucleotide conjugates directly from crosslinked and completely hydrolyzed RNP complexes without the need for time-consuming SE chromatography, ethanol precipitation, and stepwise digestion of the protein and RNA moieties. Moreover, the use of nanochromatographic equipment (i.e., fused silica with i.d. of 50 to $100 \mu \mathrm{m}$ for analytical columns and with 150 to $300 \mu$ m i.d. for precolumns) reduced the sample amount that was loaded on the system and still allowed detection and sequencing of the crosslinked species down to $4 \mu \mathrm{g}$ (12 pmol).

On-line coupling of $\mathrm{TiO}_{2}$ columns into a HPLC system or integrated within a nanochip has recently been reported for the enrichment of phosphopeptides from mixtures. ${ }^{18,19,21}$ Although comparable to our system, in that two C18 trapping columns were used for additional desalting steps before and after the enrichment procedure and thus nonphosphorylated peptides can be directly analyzed in the flow-through by MS, this particular setting cannot be used for the enrichment of peptide-RNA crosslinks from mixtures. Both of the systems described by these authors use a series connection (hence termed "sandwich" set-up) of $\mathrm{C} 18$ precolumn, $\mathrm{TiO}_{2}$ column, and C18 precolumn for the three chromatic steps of desalting, enrichment, and desalting before the final separation of the enriched species. In contrast, the first desalting step in our case achieved the removal of the excess of non- 
crosslinked RNA moiety. In a series connection the RNA moiety would be washed directly onto the $\mathrm{TiO}_{2}$ column and thus would presumably drastically minimize the binding capacity of the $\mathrm{TiO}_{2}$ as it strongly interacts with the column material trough the phosphate backbone of the RNA. Moreover, the RNA would be eluted onto the analytical column during the further chromatographic steps and would then drastically interfere with the detection of other species in the MS (F.R., H.U., data not shown). For these reasons we had to use a two-valve system (as is, for example, realized within the dual-gradient system from Dionex/LC packings company) in which two trapping columns and $\mathrm{a} \mathrm{TiO}_{2}$ could be mounted, loaded, and washed independently of each other. This enabled us to remove the excess of noncrosslinked RNA from the entire system.

In this feasibility study, we coupled the chromatography system via a MALDI target spotter to MALDI MS and MSMS analysis. At present we consider this to be advantageous for several reasons: (i) TFA can be used as an additive in loading, in washing and in both the separation steps. In general TFA yields better separations of the crosslinked species as compared with formic acid in RP-LC (H.U, unpublished data) owing to its strong ion-pairing properties, but it is still completely compatible with MALDI analysis, although not with ESI MS at suitable concentrations [i.e., $\geq 0.1 \%(\mathrm{v} / \mathrm{v}){ }^{28,29}$ (ii) We found that loading and washing conditions with $0.25 \%$ $(\mathrm{v} / \mathrm{v})$ TFA generate a $\mathrm{pH}$ value of 1.5 , which is close to the $\mathrm{pI}$ of an organic phosphate group and is still suitable for RPchromatography. Recently Jensen and Larsen ${ }^{22}$ and Thingholm et al. ${ }^{16}$ described an optimized protocol for the efficient enrichment of phosphopeptides by $\mathrm{TiO}_{2}$ using highly acidic conditions (5\% TFA) in combination with $200 \mathrm{mg} / \mathrm{ml} \mathrm{DHB}$. Unfortunately such conditions are not compatible with online $\mathrm{TiO}_{2}$-LC separations. (iii) 2,5-DHB as MALDI matrix in combination with up to $1 \%$ phosphoric acid has been shown to increase dramatically the signal intensity in MS mode of phosphopeptides ${ }^{30}$ and peptide-RNA crosslinks. ${ }^{6}$ (iv) In general MALDI analysis of spotted fractions allows the fully automated MS and MSMS analysis of selected precursors. ${ }^{31}$ An advantage over ESI in this case is that samples can be reinvestigated once an enriched precursor has been identified as potentially containing a crosslink (or as potentially being a phosphopeptide). Initial MSMS analysis in MALDI easily reveals the loss of phosphate, even in low-abundance samples in a first investigation. Upon reinvestigation of the same spot, the remaining amount of precursor can be used for more indepth sequencing by MSMS.

In recent phosphoproteomics applications, bound species are eluted from $\mathrm{TiO}_{2}$ by a shift from $\mathrm{pH}<1$ (5\% TFA, loading, and washing) to $\mathrm{pH} 10.5\left(\mathrm{NH}_{4} \mathrm{OH}\right)$. We also tested
$\mathrm{NH}_{4} \mathrm{OH}$ in our on-line settings but observed that the $\mathrm{TiO}_{2}$ columns (at least in our hands) did not withstand these strongly basic conditions, so that $\mathrm{TiO}_{2}$ columns had to be changed after each separation cycle. We therefore used $75 \mathrm{mM}\left(\mathrm{NH}_{4}\right)_{2} \mathrm{HPO}_{4} \mathrm{pH} 1.1$ in water. $\left(\mathrm{NH}_{4}\right)_{2} \mathrm{HPO}_{4}$ allowed us to use higher $\mathrm{PO}_{4}$-concentrations giving a lower $\mathrm{pH}$ value than obtained from the same concentration of $o$-phosphoric acid alone. In our previous studies we successfully applied phosphoric acid as a replacement for peptide-RNA oligonucleotides from IMAC beads. ${ }^{12}$ In the work presented here, we were able to demonstrate that $\mathrm{PO}_{4}$ also works for elution from $\mathrm{TiO}_{2}$ and, importantly, that the $\mathrm{TiO}_{2}$ column could be used up to 30 times without significant loss in its binding properties. Along the same lines, Jensen and Larsen ${ }^{22}$ observed a compromising effect of phosphate ions in buffers for the binding of phosphopeptides, supporting our finding that inorganic phosphate is an applicable reagent for the elution of phosphate-containing species.

As described earlier, TFA as ion-pairing reagent interferes with ESI-MS. Future studies should therefore investigate whether alternative ESI compatibles additives (like formic acid or acetic acid, as used by Cantin et al., ${ }^{20}$ Pinkse et al., ${ }^{18}$ and Mohammed et $\mathrm{al}^{21}$ ) are appropriate for loading and washing of $\mathrm{TiO}_{2}$ columns for the enrichment of crosslinked species. We recently demonstrated that crosslinked species can be detected and sequenced by multiple reaction monitoring-triggered MSMS in an ESI hybrid linear ion trap/triple quadrupole MS in the positive mode using "standard" ESI$\mathrm{RP}$ solvent, i.e., ACN and FA. ${ }^{10}$ Coupling our $2 \mathrm{D}$ system to an ESI linear ion trap/triple quadrupole MS would enable a high-throughput analysis of different UV-irradiated proteinRNA complexes.

\section{MATERIALS AND METHODS}

\section{Sample Preparation}

Spliceosomal [15.5K-61k-U4 snRNA] and U1 snRNPs were reconstituted and purified as described elsewhere. ${ }^{25,26}$ For crosslinking, $6.75 \mathrm{nmol}(470 \mu \mathrm{g})$ and $152 \mathrm{pmol}(50 \mu \mathrm{g})$ of the complexes, respectively, were UV-irradiated at $254 \mathrm{~nm}$ in a volume of $12 \mathrm{ml}$ glass dishes (in-house) and $3 \mu \mathrm{l} \times 100 \mu \mathrm{l}$ in low-adhesive, flat-bottomed microtiter plates (Greiner), respectively, for $3 \mathrm{~min}$ as described in Urlaub et al. ${ }^{7,8}$ Irradiated samples are precipitated with ethanol, washed, and dried in a SpeedVac exactly as described in KühnHölsken et al. ${ }^{6}$ Samples were dissolved in $4 M$ urea, $50 \mathrm{mM}$ Tris- $\mathrm{HCl}$ $\mathrm{pH}$ 7.5. After dilution to $1 M$ urea using $50 \mathrm{mM}$ Tris- $\mathrm{HCl} \mathrm{pH} 7.5$, the RNA was digested by adding $1 \mu \mathrm{g}$ RNase A, $1 \mu \mathrm{g}$ RNase T1, and $125 \mathrm{U}$ benzonase at $52^{\circ} \mathrm{C}$ for $2 \mathrm{~h}$. Subsequently the protein moiety was digested by adding $7.5 \mu \mathrm{g}$ trypsin (modified, Promega) (enzyme:substrate ratio $1: 20$ ) at $37^{\circ} \mathrm{C}$ overnight. [15.5K-61K-U4atac 
snRNA] complexes were digested with $23.5 \mu \mathrm{g}$ chymotrypsin (Roche) at $37^{\circ} \mathrm{C}$ over night.

The U1 70K peptide crosslink (RVLVDVER) was purified on a semipreparative scale from UV-irradiated U1 snRNPs exactly as described by Kühn-Hölsken et al. ${ }^{6}$ Purified fractions were dried in a speed-vac and stored for further use.

\section{Enrichment of Phosphopeptides and Crosslinks by Off-Line $\mathrm{TiO}_{2}$ in Batch}

A slurry from $\mathrm{TiO}_{2}$ bulk material $(5 \mathrm{mg} / \mathrm{ml})$ in loading buffer $0.25 \%(\mathrm{v} / \mathrm{v})$ TFA, $50 \%(\mathrm{v} / \mathrm{v})$ ACN was prepared and $20 \mu \mathrm{l}$ aliquots (equivalent to $0.1 \mu \mathrm{g}$ ) were used for batch enrichment. Sample was loaded in $50 \mu$ loading buffer by vigorous shaking for $15 \mathrm{~min}$. Then $\mathrm{TiO}_{2}$ particles were sedimented at $13,000 \mathrm{rpm}$ and the supernatant was collected. Washing was performed with two increasing concentrations of $\mathrm{ACN}[25 \%(\mathrm{v} / \mathrm{v})$ and $50 \%(\mathrm{v} / \mathrm{v})]$ again incubating for $15 \mathrm{~min}$. Finally, the sample was eluted twice with $50 \mu \mathrm{l}\left(\mathrm{NH}_{4}\right)_{2} \mathrm{HPO}_{4}$ $\mathrm{pH} 1.1$ buffer and phosphorylated and crosslinked peptides were recovered onto stage tips (C18 3M Empore Disk incorporated into gel loader tips). All steps were monitored by preparing equivalent amounts of sample $(0.5 \mu \mathrm{l}$ from $50 \mu \mathrm{l})$ onto Bruker Anchor MALDI plates using 2,5-DHB matrix.

\section{D/2D Chromatography Setup}

The on-line chromatography system (1D and 2D) was mounted into an Ultimate Dual Gradient System (Dionex, Idstein, Germany) equipped with an autosampler (Sparck, Emmen, Netherlands), and a multichannel UV detector (Dionex) with a 3 nl flow cell. Analytical columns were prepared in fused silica capillaries (PT Polymicro Technologies L.L.C.) with $75 \mu \mathrm{m}$ i.d. and $375 \mu \mathrm{m}$ o.d that had been capped on one side by a Kasil ${ }^{\mathrm{TM}}$ (PQ Europe) frit of 2-5 mm length. Analytical columns were packed by using a pressure vessel for column packing (Bruchbühler, CH) using Vydac 218TP5215 material (particle size $5 \mu \mathrm{m}$, pore width $300 \AA$ 作 Vydac, Columbia, molecular dynamics (MD), USA) to a length of $\sim 15 \mathrm{~cm}$. Precolumns were prepared from either ReproSil-Pur Basic C18-HD (5 $\mu$ m particle size, $120 \AA$ pore width, Dr. Maisch GmbH, Ammerbuch, Germany) or Vydac 218TP5215 material in the same manner by using fused silica capillaries with $150 \mu \mathrm{m}$ i.d. and $375 \mu \mathrm{m}$ o.d. Precolumns were trimmed to a length of $2.5 \mathrm{~cm}$ and capped at both ends with MicroTight Fittings with $0.5-\mu \mathrm{m}$ peek filter end fittings (UpChurch Scientific, Oak Harbor, WA). Titanium dioxide enrichment columns with $100 \mu \mathrm{m}$ i.d. were prepared in the same manner using $5 \mu \mathrm{m}$ titanium dioxide beads (Sigma Aldrich) that had been washed free from smaller debris.

Connecting capillaries had an i.d. of $25 \mu \mathrm{m}$ for standard 1D chromatography and $50 \mu \mathrm{m}$ for $2 \mathrm{D}$ chromatography set-up. The loading pump was operated at a flow rate of $9 \mu \mathrm{l} / \mathrm{min}$ (1D) and $5 \mu \mathrm{l} / \mathrm{min}(2 \mathrm{D})$ with loading solvent [3.5\% (v/v) ACN $/ 0.1 \%(\mathrm{v} / \mathrm{v})$ TFA]. The nanopump was run at $300 \mu \mathrm{l} / \mathrm{min}$, generating a gradient from 10 to $60 \%$ solvent $B_{1}$. Solvents were as follows: for standard 1D LC, solvent A was $0.1 \%(\mathrm{v} / \mathrm{v})$ TFA in water and solvent B was $80 \%(\mathrm{v} / \mathrm{v}) \mathrm{ACN} / 0.1 \%(\mathrm{v} / \mathrm{v})$ TFA in water; for $2 \mathrm{D}$ chromatography solvent $A_{1}$ and $A_{2}$ were $0.25 \%(v / v)$ TFA and solvents $B_{1}$ and $B_{2}$ were $80 \%(\mathrm{v} / \mathrm{v})$ ACN $/ 0.25 \%(\mathrm{v} / \mathrm{v})$ TFA. The capillary pump operated at a flow rate of $3.5 \mu \mathrm{l} / \mathrm{min}$ with solvents $\mathrm{A}_{2}$ and $\mathrm{B}_{2}$ or with solvent $\mathrm{C}$ for elution $\left(10 \mathrm{mg} / \mathrm{ml}(75 \mathrm{mM})\left(\mathrm{NH}_{4}\right)_{2} \mathrm{HPO}_{4} \mathrm{pH} 1.1\right)$.

\section{D/2D Workflow}

For 1D separation, samples were loaded for 15 min onto the precolumn and eluted by backflush on the analytical column. Separation was carried out for $120 \mathrm{~min}$. The analytical column was washed with $80 \%(\mathrm{v} / \mathrm{v})$ ACN, $0.1 \%$ TFA for $9 \mathrm{~min}$, and re-equilibrated under starting conditions [10\% ACN $(\mathrm{v} / \mathrm{v})]$.

The column configurations of the $2 \mathrm{D}$ set-up are illustrated in Figure 3. The initial 10-port valve configuration was 10-1/1-2. The sample was loaded for 25 min onto the precolumn. During loading in this configuration the $\mathrm{TiO}_{2}$ column was equilibrated with $48 \%$ $\mathrm{ACN}, 0.25 \%(\mathrm{v} / \mathrm{v})[60 \%(\mathrm{v} / \mathrm{v})$ solvent $\mathrm{B}] \mathrm{TFA}$ in water using the capillary pump at a flow of $3.5 \mu \mathrm{l}$ and the second precolumn was equilibrated at $300 \mathrm{nl} / \mathrm{min}$ with $8 \% \mathrm{ACN}(\mathrm{v} / \mathrm{v}), 0.25 \% \mathrm{TFA}(\mathrm{v} / \mathrm{v})$ using the nanopump. By switching the two 10-port valves simultaneously, 1-2 and 10-1, the samples were eluted from the precolumn to the $\mathrm{TiO}_{2}$ column and to the analytical column by applying a gradient of 0 to $48 \%$ ACN (v/v), $0.25 \%$ TFA for $120 \mathrm{~min}$ via the nanopump. By switching the valves to positions 1-2 and 1-2, bound species on the $\mathrm{TiO}_{2}$ column were eluted with $75 \mathrm{mM}\left(\mathrm{NH}_{4}\right)_{2} \mathrm{HPO}_{4} \mathrm{pH}$ 1.1 for $35 \mathrm{~min}$ at a flow rate of $3.5 \mu$ l onto the second precolumn (ReproSil-Pur Basic C18-HD). The precolumn was flushed with $2.5 \%$ TFA in water for $30 \mathrm{~min}$. During this time the analytical column was equilibrated with $0.25 \%$ TFA (v/v) $\left(100 \%\right.$ solvent $\left.A_{1}\right)$ at a flow rate of $300 \mathrm{nl} / \mathrm{min}$ by the nanopump. Elution of the bound species from the precolumn is achieved by switching the valves to positions 10-1 and 1-2 and applying a gradient of 0 to $48 \%$ ACN (v/v), $0.25 \%$ TFA (v/v) (0 to $60 \%$ solvent $\left.B_{1}\right)$ in TFA water for $120 \mathrm{~min}$.

\section{MALDI Mass Spectrometry}

The eluate in $1 \mathrm{D}$ or in $2 \mathrm{D}$ chromatography from the first and second gradient was mixed in a 29-nl T-piece (UpChurch Scientific, Oak Harbor, WA) with either $\alpha$-cyano-4-hydroxy cinnamic acid [HCCA, $10 \mathrm{mg} / \mathrm{ml}$ in 70\% (v/v) ACN $/ 0.1 \%(\mathrm{v} / \mathrm{v})$ TFA] containing $10 \mathrm{fmol} / \mu \mathrm{l}$ Glu-fibrinogen peptide $(\mathrm{m} / z \mathrm{1570}$, Sigma) as internal standard (1D standard LC) or with 2,5-dihydroxybenzoic acid [DHB, $10 \mathrm{mg} / \mathrm{ml}$ in 20\% (v/v) ACN/0.1\% (v/v) $\mathrm{H}_{3} \mathrm{PO}_{4}$ containing an internal standard Glu-fibrinogen peptide], respectively, delivered at a flow rate of $0.9 \mu \mathrm{l} / \mathrm{min}$. Fractions were spotted every $15 \mathrm{~s}$ $(\alpha$-cyano $)$ onto LC-MALDI stainless steel plates or every $30 \mathrm{~s}$ (DHB) onto 384er stainless steel MALDI targets (Applied Biosystems/Sciex MDS, Foster City) and 384er Bruker Anchor600 chip plates (Bruker-Daltonics, Bremen, Germany) by a Probot Spotter (Dionex, Idstein Germany). MS analysis was performed either on a MALDI-ToF/ToF 4800 proteome analyzer (Applied Biosystems/ Sciex MDS, Foster City) or a Bruker Reflex IV instrument (BrukerDaltonics, Bremen, Germany). For MS spectra in positive-ion mode on an ABI $4800 \mathrm{ToF} / \mathrm{ToF}$ analyzer, a total of 800 shots were generated and for MSMS a maximum of 5000 shots were accumulated for each precursor, using dynamic stop criteria depending on the spectral quality. Job-wide interpretation of the $4800 \mathrm{ToF} / \mathrm{ToF}$ analyzer generated MS data allowed the 15 highest peptides in intensity for sequencing in MSMS mode. Collision energy was set to $1 \times$ $10^{-6}$ torr, with potential difference between the source acceleration voltage and the collision cell set at $1 \mathrm{kV}$. For MS spectra in positiveion mode on a Bruker Ultraflex IV instrument, 200 shots were summed up. If a suitable high amount of precursor was detected, one MALDI-PSD spectrum from a spot could be detected. PSD spectra were recorded with an acceleration voltage of $25 \mathrm{kV}$ (IS1) 
and $20.2 \mathrm{kV}$ (IS2). The delay time was $200 \mathrm{~ns}$, and a total of 210 laser shots were summed for each PSD segment.

The authors thank Monika Raabe for excellent technical assistance in preparing U snRNPs, UV irradiation, and semipreparative purification of crosslinked samples. They also thank Hossein Kohansal and Reinhard Lührmann for providing the nuclear extract.

\section{REFERENCES}

1. Will, C. L.; Lührmann, R. Curr Opin Cell Biol 2001, 13, 290301.

2. Blencowe, B. J. Cell 2006, 126, 37-47.

3. Mallory, A. C.; Vaucheret, H. Nat Genet 2006, 38 (Suppl), S31S36.

4. Kloosterman, W. P.; Plasterk, R. H. Dev Cell 2006, 11, 441-450.

5. Steen, H.; Petersen, J.; Mann, M.; Jensen, O. N. Protein Sci 2001, 10, 1989-2001.

6. Kühn-Hölsken, E.; Lenz, C.; Sander, B.; Lührmann, R.; Urlaub, H. RNA 2005, 11, 1915-1930.

7. Urlaub, H.; Hartmuth, K.; Kostka, S.; Grelle, G.; Lührmann, R. J Biol Chem 2000, 275, 41458-41468.

8. Urlaub, H.; Hartmuth, K.; Lührmann, R. Methods 2002, 26, 170-181.

9. Urlaub, H.; Raker, V. A.; Kostka, S.; Lührmann, R. EMBO J 2001, 20, 187-196.

10. Lenz, C.; Kühn-Hölsken, E.; Urlaub, H. J Am Soc Mass Spectrom 2007, 18, 869-881.

11. Geyer, H.; Geyer, R.; Pingoud, V. Nucleic Acids Res 2004, 32, e132.

12. Kühn-Hölsken, E.; Dybkov, O.; Sander, B.; Lührmann, R.; Urlaub, H. Nucleic Acids Res 2007, 35, e95.

13. Larsen, M. R.; Thingholm, T. E.; Jensen, O. N.; Roepstorff, P.; Jorgensen, T. J. Mol Cell Proteomics 2005, 4, 873-886.

14. Andersson, L.; Porath, J. Anal Biochem 1986, 154, 250-254.
15. Bodenmiller, B.; Mueller, L. N.; Mueller, M.; Domon, B.; Aebersold, R. Nat Methods 2007, 4, 231-237.

16. Thingholm, T. E.; Jensen, O. N.; Robinson, P. J.; Larsen, M. R. Mol Cell Proteomics 2008, 7, 661-671.

17. Pinkse, M. W.; Uitto, P. M.; Hilhorst, M. J.; Ooms, B.; Heck, A. J. Anal Chem 2004, 76, 3935-3943.

18. Pinkse, M. W.; Mohammed, S.; Gouw, J. W.; van Breukelen, B.; Vos, H. R.; Heck, A. J. J Proteome Res 2008, 7, 687-697.

19. Albuquerque, C. P.; Smolka, M. B.; Payne, S. H.; Bafna, V.; Eng, J.; Zhou, H. Mol Cell Proteomics 2008, 7, 1389-1396.

20. Cantin, G. T.; Shock, T. R.; Park, S. K.; Madhani, H. D.; Yates, J. R., III. Anal Chem 2007, 79, 4666-4673.

21. Mohammed, S.; Kraiczek, K.; Pinkse, M. W.; Lemeer, S.; Benschop, J. J.; Heck, A. J. J Proteome Res 2008, 7, 1565-1571.

22. Jensen, S. S.; Larsen, M. R. Rapid Commun Mass Spectrom 2007, 21, 3635-3645.

23. Shevchenko, A.; Tomas, H.; Havlis, J.; Olsen, J. V.; Mann, M. Nat Protoc 2006, 1, 2856-2860.

24. Rappsilber, J.; Ishihama, Y.; Mann, M. Anal Chem 2003, 75, 663-670.

25. Nottrott, S.; Hartmuth, K.; Fabrizio, P.; Urlaub, H.; Vidovic, I.; Ficner, R.; Luhrmann, R. EMBO J 1999, 18, 6119-6133.

26. Nottrott, S.; Urlaub, H.; Lührmann, R. EMBO J 2002, 21, 55275538.

27. Stensballe, A.; Andersen, S.; Jensen, O. N. Proteomics 2001, 1, 207-222.

28. Garcia, M. C. J Chromatogr B Anal Technol Biomed Life Sci 2005, 825, 111-123.

29. Apffel, A.; Fischer, S.; Goldberg, G.; Goodley, P. C.; Kuhlmann, F. E. J Chromatogr A 1995, 712, 177-190.

30. Kjellstrom, S.; Jensen, O. N. Anal Chem 2004, 76, 5109-5117.

31. Zhen, Y.; Xu, N.; Richardson, B.; Becklin, R.; Savage, J. R.; Blake, K.; Peltier, J. M. J Am Soc Mass Spectrom 2004, 15, 803-822.

Reviewing Editor: Dan Fabris 